\title{
Cytochrome Oxidase 2 (COX2), $\beta$-Tubulin $(T U B)$ and Chitin Synthase Subunit 2 (CHS2) Expression in Pythium insidiosum Thai Strains
}

\section{Patcharee KAMMARNJASSADAKUL ${ }^{1, *}$, Watcharin RANGSIPANURATN ${ }^{1}$, Methee SRIPRAPUN ${ }^{2}$, Popchai NGAMSAKULRUNGRUJ ${ }^{3}$, Tanapat PALAGA ${ }^{4}$, Kallaya SRITUNYALUCKSANA ${ }^{5}$ and Ariya CHINDAMPORN ${ }^{6}$}

\author{
${ }^{I}$ Faculty of Medical Technology, Huachiew Chalermprakiat University, Samut Prakan 10540, Thailand \\ ${ }^{2}$ Faculty of Pharmacy, Mahidol University, Bangkok 10400, Thailand \\ ${ }^{3}$ Faculty of Medicine Siriraj Hospital, Mahihol University, Bangkok 10400, Thailand \\ ${ }^{4}$ Faculty of Science, Chulalongkorn University, Bangkok 10330, Thailand \\ ${ }^{5}$ Faculty of Science, Mahidol University, Bangkok 10400, Thailand \\ ${ }^{6}$ Faculty of Medicine, Chulalongkorn University, Bangkok 10330, Thailand
}

('Corresponding author's e-mail: kpatcharee@gmail.com)

Received: 27 January 2020, Revised: 25 June 2020, Accepted: 23 July 2020

\begin{abstract}
This study aimed to investigate the real-time fluctuation of temperature-sensitive gene expression in a Pythium insidiosum growing at human body temperature $\left(37^{\circ} \mathrm{C}\right)$ when it can cause life-threatening disease, whereas its natural habitat is in agricultural water sources with lower temperature. Genes encoding cytochrome oxidase 2 (COX2), $\beta$-tubulin $(T U B)$, and chitin synthase subunit 2 (CHS2) were tested for their expression at the infection temperature $\left(37^{\circ} \mathrm{C}\right)$ and natural habitat temperature $\left(27{ }^{\circ} \mathrm{C}\right)$ using real-time RT-PCR. Sixteen strains of $P$. insidiosum, representing 3 phylogeographic preferences, were analyzed. The subculturing process at $27{ }^{\circ} \mathrm{C}$ was repeated at least $2-3$ cycles. The results showed that at $37^{\circ} \mathrm{C}$, the $C O X 2$ was expressed 2.5 -fold higher than that of $27{ }^{\circ} \mathrm{C}(p=0.0347)$ while the level of $T U B$ and $C H S 2$ mRNA disclosed indistinguishable profiles. These results suggested that these genes were suitable to be used as housekeeping genes for temperature-susceptible gene expression studies. This work was likely to be the $1^{\text {st }}$ study examining the gene expression levels of the Thai strain of $P$. insidiosum under thermal stress conditions. Follow-up studies for the $C O X 2$ genes may useful to provide valuable insight into the pathogenesis, diagnostic, or therapeutic targets for further investigation.
\end{abstract}

Keywords: Chitin synthase 2, Cytochrome oxidase 2, Expression, Pythium insidiosum, Tubulin

\section{Introduction}

Pythium insidiosum (P. insidiosum) has been reported as a human and animals' pathogen [1-3]. The disease caused by this pathogen, called "pythiosis", is found in the tropical, subtropical, and temperate regions of the world $[4,5]$. The phylogeographic preferences of $P$. insidiosum isolates from different geographic regions were revealed the existence of three phylogenetic using an internal transcribed spacer (ITS), intergenic spacer (IGS) sequences, and cytochrome oxidase (COX2) gene [6]. Recently, phylogenetic analysis of the environmental strains of $P$. insidiosum using the ITS regions and revealed that these strains have phylogenetic features in common with the clinical isolate recovered from humans and animals [6,7]. Clinical manifestations of pythiosis include cutaneous/subcutaneous, ocular, vascular, and disseminated forms. Human pythiosis cases are frequently detected in Thailand. Vascular pythiosis is the most common manifestation of human pythiosis, which almost always occurs in patients with underlying hemoglobinopathy complicated by hemochromatosis $[8,9]$. 
http://wjst.wu.ac.th

The life cycle of $P$. insidiosum consists of 2 phases, each with a unique range of temperature: A saprophytic phase in the aquatic reservoir with a temperature range of $25-30{ }^{\circ} \mathrm{C}$, and a parasitic phase in mammals at approximately $37^{\circ} \mathrm{C}[10]$. It is already known that the ability of pathogenic microorganisms to grow at $37^{\circ} \mathrm{C}$ is a prerequisite significant factor to cause disease in hosts, whereas the failure to grow at $37{ }^{\circ} \mathrm{C}$ is a predictive indicator of attenuated virulence. Our preliminary experiment showed that the growth of the $1^{\text {st }}$ isolates of $P$. insidiosum from human tissue biopsy at $37^{\circ} \mathrm{C}$ was significantly faster than incubation at $27^{\circ} \mathrm{C}$. If the virulence is related to the ability to grow at $37^{\circ} \mathrm{C}$, then all clinical and some potentially virulent environmental strains of $P$. insidiosum will have the ability to survive at the expected higher temperature to express possible virulence characteristics.

Based on recently available data, with an emphasis on the ability to survive at different temperatures $\left(27\right.$ and $37^{\circ} \mathrm{C}$ ), 3 distinct clades based on geographical areas were reported but no data has been published on studies at the genetic level. In this study, we determined candidate genes Cytochrome oxidase 2 (COX2), $\beta$-tubulin (TUB), and chitin synthase 2 (CHS2) which may be temperature-sensitive gene expression levels at $37^{\circ} \mathrm{C}$ from each clade of $P$. insidiosum, using real-time RT-PCR. The results of this study present the fundamental information that could be used to support future research, leading to a better understanding of the mechanisms of this organism to cause disease which may lead to better treatment.

\section{Materials and methods}

\section{Strains}

Sixteen isolates of $P$. insidiosum from clinical (human and animals) and environmental sources were used in this study. All of these aquatic fungus-like organisms were isolated from the proven cases of pythiosis, confirmed by western blot analysis. All strains were tested for their ability of zoospore production and maintained on Sabouraud dextrose agar (SDA) (Bio-Rad) at $37^{\circ} \mathrm{C}$. To prepare the isolate for the quantitative gene expression study at $27{ }^{\circ} \mathrm{C}$, the submerged fungal-like colonies growing from SDA at $37^{\circ} \mathrm{C}$ were subcultured on SDA and incubated for 7 days at $27^{\circ} \mathrm{C}$. The subculturing process at $27^{\circ} \mathrm{C}$ was repeated at least 2 - 3 cycles.

\section{RNA extraction}

The 7-day-old colonies of each active strain were inoculated into $300 \mathrm{~mL}$. Sabouraud dextrose broth (SDB) (Difco) and incubated at 37 or $27{ }^{\circ} \mathrm{C}$ depending on the original incubation temperature and shook at $155 \mathrm{round} / \mathrm{min}(\mathrm{rpm})$ for 5 days in a shaking incubator. Prior to RNA extraction, the mycelial masses were filtered using a $0.22 \mu \mathrm{m}$ pore size PES membrane filter (Corning) and ground in liquid nitrogen. To extract RNA, a hot phenol extraction method [11] was used. The precipitation step was performed twice as well, at -20 and $-70{ }^{\circ} \mathrm{C}$ using RNA precipitation solution of cold isopropanol. Finally, the pellets were suspended in sterile RNase-free water. The quality and quantity of this total RNA were measured by using denatured gel electrophoresis and NanoDrop spectrophotometer (Thermocycler). RNA concentration was calculated based on the optical density (OD) at A260 using Beer-Lambert law [12].

\section{First-strand cDNA synthesis and real-time reverse-transcriptase PCR (real-time RT-PCR)}

The DNase digestion reaction using RQ1 RNase-Free DNase (Promega) was set up following the manufacturer's protocol. The cDNA was synthesized from an mRNA template using The RevertAidTM $1^{\text {st }}$ Strand cDNA Synthesis kit (Fermentas). The $20 \mu \mathrm{L}$ reaction mixture contained $3 \mu \mathrm{g}$ DNA-free RNA and $0.5 \mu \mathrm{g}$ Oilgo (dT)18 primer, 1x Reaction Buffer, $20 \mathrm{U}$ RiboLockTM Ribonuclease Inhibitor, $1 \mathrm{mM}$ dNTPs and $10 \mathrm{U}$ RevertAidTM A-MuLV Reverse Transcriptase. The reaction was incubated at $42{ }^{\circ} \mathrm{C}$ for $1 \mathrm{~h}$ and followed by incubating at $70{ }^{\circ} \mathrm{C}$ for $5 \mathrm{~min}$. To quantify the level of mRNA expression, the LightCycler FastStart DNA Master SYBR Green I kit (Roche) was used for this experiment. The PCR mixture for a $20 \mu \mathrm{L}$ standard reaction contained 1x LightCycler FastStart DNA Master SYBR Green I, $0.2 \mu \mathrm{M}$ of each primer (Table 1), $0.2 \mu \mathrm{M}$ of $\mathrm{MgCl}_{2}$ and $2 \mu \mathrm{g}$ of cDNA templates. The program consisted of an initial pre-incubation step $\left(10 \mathrm{~min}\right.$ at $\left.95^{\circ} \mathrm{C}\right)$, followed by 45 PCR cycles $\left(10 \mathrm{~s}\right.$ at $95^{\circ} \mathrm{C}, 10 \mathrm{~s}$ at $55^{\circ} \mathrm{C}$ and $25 \mathrm{~s}$ at $\left.72^{\circ} \mathrm{C}\right)$ and a melting curve step $\left(55-95^{\circ} \mathrm{C}\right)$, then cooling to $40{ }^{\circ} \mathrm{C}$. 
http://wjst.wu.ac.th

Table 1 List of primers used for real-time PCR of the COX2, ITS regions, TUB, and CHS2.

\begin{tabular}{|c|c|c|}
\hline Primer & Sequence (5'-3') & PCR product (bp) \\
\hline \multicolumn{3}{|l|}{$\operatorname{COX} 2$ region } \\
\hline Forward: FM58 & 5'- CCACAAATTTCACTACATTGA- 3' & 600 \\
\hline Reverse: FM66 & 5'- TAGGATTTCAAGATCCTGC- 3' & \\
\hline \multicolumn{3}{|l|}{ ITS region } \\
\hline Forward: ITS-1 & 5'- TCCGTAGGTGAACCTGCGG- 3' & 550 \\
\hline Reverse: ITS-4 & 5'- TCCTCCGCTTATTGATATGC- $3^{\prime}$ & \\
\hline \multicolumn{3}{|l|}{$T U B$} \\
\hline Forward: TubuF & 5'- AACGCCGAAGAGGTCATG-3' & 500 \\
\hline Reverse: TubuR & 5'- CCAGGAGATGTTCAAGCG-3' & \\
\hline \multicolumn{3}{|l|}{ CHS2 } \\
\hline Forward: ChiF & 5'- GAACACTCACAGGCATCGCAAG-3' & 900 \\
\hline Reverse: ChiR & 5'- GGGTTACGATCCATGCTTC-3' & \\
\hline
\end{tabular}

\section{Data analysis}

The most common analysis of the Comparative threshold (CT) method is $\Delta \Delta \mathrm{CT}$ [13], where $\Delta \Delta \mathrm{CT}$ $=\Delta \mathrm{CT} 37^{\circ} \mathrm{C}-\Delta \mathrm{CT} 27^{\circ} \mathrm{C}$ and $\Delta \mathrm{CT}=\mathrm{CT}$ target gene $-\mathrm{CT}$ reference gene. The comparative expression level was calculated using $2-\Delta \Delta \mathrm{CT}$. Graphpad Prism ${ }^{\circledR}$ software was used for reporting data and performing statistical analyses. Data were expressed as mean + standard deviation (SD). The statistical difference of each pair was evaluated by Student's t-test using a generic approach. The level of statistical significance was set at $p<0.05$.

\section{Results and discussion}

Reference (housekeeping) genes have been described in the literature and many different genes are currently in use $[14,15]$. For the real-time RT-PCR, the average cycle threshold $\left(\mathrm{C}_{T}\right)$ values of ITS at 27 and $37{ }^{\circ} \mathrm{C}$ conditions were $26.68 \pm 3.95$ and $26.27 \pm 3.6$, respectively. The Student's t-test indicated that the cycle threshold of ITS between 27 and $37{ }^{\circ} \mathrm{C}$ conditions were not statistically different $(p=$ 0.3201). Thus, these data suggested that ITS rRNA is suitable for a reference control for quantitative gene expression analysis. Sixteen strains of $P$. insidiosum were representative of 3 phylogeographic preferences clades, based on ITS $1 / 2$ and $C O X 2$. The transcriptional quantifications of three genes $(C O X 2$, $T U B$, and $C H S 2$ ) were performed using quantitative real-time RT-PCR. Furthermore, the melting curve analysis of post-amplification revealed that $C O X 2$ and $T U B$ specific primer pairs produced a single peak in the dissociation curve, indicating that no nonspecific products were amplified. Hence, it was established that $T U B$-specific primers specifically amplified the $\beta$-tubulin gene of $P$. insidiosum without producing any significant number of nonspecific products. Two peaks were generated from ITS and CHS2 specific primers in melting curve analysis however the left peak indicated a lower melting temperature. These might suggest a primer-dimer artifact because a single band of each primer pairs was revealed on $1.5 \%$ agarose gel electrophoresis, whereas the negative control did not appear. In addition to confirming the PCR products of real-time PCR, they were also sequenced and analyzed with GenBank databases. Fragments of rRNA, $C O X 2, T U B$, and $C H S 2$ products showed the Tm values, of approximately $88.4,78.7,90.2$, and $88.9^{\circ} \mathrm{C}$, respectively. 
Transcription profiling of 3 candidate genes (COX2, TUB, and CHS2) was performed using realtime RT-PCR in various culturing temperatures. The transcripts of the 3 genes were analyzed in individual $P$. insidiosum strain samples by direct comparison of their cycle threshold $\left(\mathrm{C}_{T}\right)$, assuming equal $\mathrm{C}_{T}$ for equal transcript number, since all real-time RT-PCR reactions were performed with an equal quantity of total RNA. To ensure precision and reproducibility, PCR was repeated three times for each sample. The results showed that $T U B$ and $C H S 2$ genes ranked according to their gene expression stability measured in both temperature conditions. Regarding the $T U B$ gene, the $\mathrm{C}_{T}$ value at $27^{\circ} \mathrm{C}$ ranged from 14 - $32(21.6 \pm 4.4)$, while the $\mathrm{C}_{T}$ value at $37^{\circ} \mathrm{C}$ spanned from $14-27(19.4 \pm 3.4)$. The $C H S 2$ gene exhibited similar results at both temperatures, with the value of $24.6 \pm 7.1$ and $22.3 \pm 5.9$, respectively. In contrast, only the COX2 gene was highly expressed as indicated by $\mathrm{C}_{T}$ values at $37{ }^{\circ} \mathrm{C}$ condition that ranged from $11-19(14.8 \pm 2)$ cycles, but it exhibited rather high dispersion over the growth at $27^{\circ} \mathrm{C}$, as indicated by a span from $10-35(19.7 \pm 8)$ cycles. The mean value, standard derivation (SD), and coefficient of variation $(\mathrm{CV})$ were then determined from the triplicate experiments. Only the COX2 mRNA was significantly up-regulated during the growth of $P$. insidiosum at high temperature $\left(37^{\circ} \mathrm{C}\right)(p=0.0347)$, whereas the expression level of the $T U B$ gene seemed to be down-regulated at $37{ }^{\circ} \mathrm{C}$. However, no statistical significance was found between the $27{ }^{\circ} \mathrm{C}$ condition and the $37{ }^{\circ} \mathrm{C}$ condition for $T U B$ ( $p=$ 0.4103 ) and $C H S 2$ mRNA expression between $37^{\circ} \mathrm{C}$ condition and $27^{\circ} \mathrm{C}$ condition $(p=0.4752)$ (Table 2). The average fold change of $C O X 2, T U B$, and $C H S 2$ genes at $27^{\circ} \mathrm{C}$ and $37^{\circ} \mathrm{C}$ conditions are shown in Figure 1.

Table 2 The fold change of the candidate temperature-sensitive genes (COX2, TUB, and CHS2 gene) relative to the reference control gene (Internal transcribed spacer, ITS) at 2 different temperature conditions $\left(27\right.$ and $\left.37^{\circ} \mathrm{C}\right)$.

\begin{tabular}{|c|c|c|c|c|c|}
\hline \multirow{2}{*}{ Gene } & \multicolumn{2}{|c|}{$\begin{array}{l}\text { Mean fold change in gene } \\
\text { expression }\end{array}$} & \multicolumn{2}{|c|}{ SD of $C_{T}$} & \multirow{2}{*}{$p$-value } \\
\hline & $27^{\circ} \mathrm{C}$ & $37^{\circ} \mathrm{C}$ & $27^{\circ} \mathrm{C}$ & $37^{\circ} \mathrm{C}$ & \\
\hline$C O X 2$ & 0.004375 & 2.52 & 5.581 & 4.41 & $0.0347^{*}$ \\
\hline$T U B$ & 0.000625 & -0.21 & 4.278 & 2.9 & 0.4103 \\
\hline CHS2 & 0.000625 & 0.05813 & 4.877 & 4.56 & 0.4752 \\
\hline
\end{tabular}

*The data was significantly at $p<0.05$. 
http://wjst.wu.ac.th

A

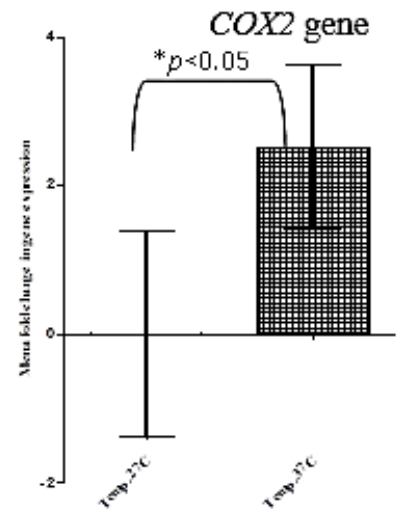

B

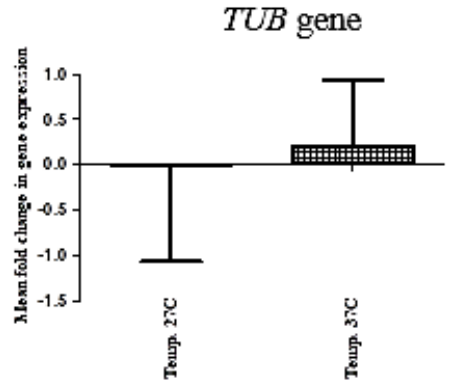

$\mathrm{C}$

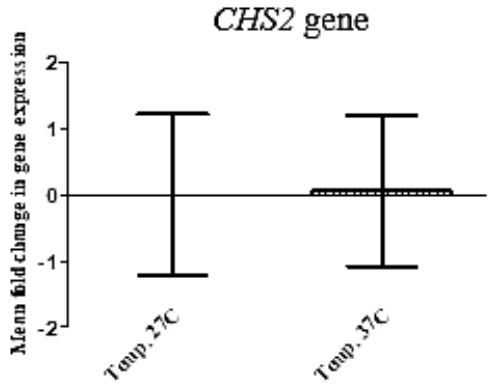

Figure 1 The relative expression of gene-encoded: Cytochrome oxidase 2 (A), $\beta$ - tubulin (B), and chitin synthase 2 (C) gene, respectively at 27 and $37{ }^{\circ} \mathrm{C}$ conditions. Boxes represent the mean of fold change. The lower and upper boundaries of the box indicate the standard error (SEM).

\section{Discussion}

It is known that the transition from an environmental reservoir into a human host is associated with temperature-regulated and virulence-related genes that contribute to the pathogenesis of pathogens such as bacteria, fungi, and protozoa. $P$. insidiosum can survive in the environment and body temperature of its mammalian host $[13,16,17]$. The genetic factors that are required for growth at $37^{\circ} \mathrm{C}$ may be worth considering as one of the various factors for the pathogenesis of P. insidiosum.

Many high-throughput techniques can be used to study transcriptomes including quantitative realtime PCR. Based on the information and genetic sequences in GenBank, 3 genes, COX2, TUB, and CHS2 were chosen for this study. Specific primers of the 2 genes; TUB and CHS2, were designed in this study, 
http://wjst.wu.ac.th

while those of COX2 and ITS were referred from Villa et al. [18] and White et al. [19], respectively. Thus, the expression of $T U B$ and $C H S 2$, which are located in nuclear DNA, appears to be temperatureindependent. This work represents the first study that examined the gene expression levels and used ITS as a reference gene in the Thai strain of $P$. insidiosum under thermal stress conditions. There have been several studies in eukaryotic gene expression using glyceraldehydes 3-phosphate dehydrogenase $(G A P D H), \beta$-actin $(A C T B)$, RNA polymerase 2 (RNAP2), ribosomal protein L13 (L13) gene, $\beta$-tubulin (TUB), 18S and 28S rRNA as housekeeping genes [20-22]. The results of real-time RT-PCR showed, that ITS (28S rRNA) was expressed consistently in both temperature conditions, thus it can be used as a control, there is evidence to support our use of $28 \mathrm{~S}$ rRNA as a control instead of housekeeping genes $[23,24]$.

$P$. insidiosum is not a true fungus because its cell walls do not contain chitin but are composed of cellulose and beta-glucan [3,25]. Interestingly, this study found that there is an expression in the chitin synthase 2 gene which is responsible for chitin synthesis. Further analysis provides evidence supporting the occurrence of chitin in the cell wall is important by using more objectives. The result found in the study is a preliminary report which should be further investigated by increasing samples in DNA sequencing to verify the results.

To achieve quantitative analysis, only the $C O X 2$ gene was expressed higher at $37^{\circ} \mathrm{C}$ than at $27^{\circ} \mathrm{C}$. The COX2 gene is part of the cytochrome oxidase complex, located in the inner mitochondria membrane. Since the structure of this complex contains pores, it facilitates the movement of protons from the mitochondria matrix to the intermembrane space, generating a proton gradient for ATP synthesis in fungi. In lower eukaryotes, this gene participates in both energetic and antioxidant defense of cells and represents an important factor for fungi [26-29]. Another example of the temperature-dependent $C O X 2$ expression was found in Saccharomyces cerevisiae temperature-sensitive strain using mutation by changing Ala189 of the Cox 2 protein to proline [30]. Based on our experiment, this is the $1^{\text {st }}$ study to show that $C O X 2$ is also temperature-dependent, however further study is needed to confirm the relationship between pathogenesis and the $C O X 2$ gene.

\section{Conclusions}

In this study, all 3 candidate genes were subjected to investigate their expression level by real-time RT-PCR. The result showed that $T U B$ and $C H S 2$, their expressions at both temperatures were difference with non-significant whereas only $C O X 2$ gene, encoded cytochrome oxidase subunit II, expressed at 37 ${ }^{\circ} \mathrm{C}$ higher than at $27{ }^{\circ} \mathrm{C}$ condition. Our study suggested that $C O X 2$ expression in P. insidiosum is temperature-dependent.

\section{Acknowledgement}

We would like to express gratitude to Prof. Boonsirm Withyachumnarnkul, Ph.D. of Mahidol University, Thailand for supporting the equipment and reagents; Assoc. Prof. Srisurang Tantimavanich, Ph.D. of Mahidol University, Thailand, Jidapa Supabandhu, Ph.D. of Prince of Songkla University, Thailand for providing $P$. insidiosum strains used during the investigation; Professor Dr. Leonel Mendoza of Michigan State University, USA for providing $P$. insidiosum strains and information about nucleotide sequences of CHS2 gene. This study was financed, by the Ratchadapisek Sompoj and Integrated Innovation Academic Center.

\section{References}

[1] W Oldenhoff, A Grooters, ME Pinkerton, J Knorr and L Trepanier. Cutaneous pythiosis in two dogs from Wisconsin, USA. Vet Dermatol. 2014; 25, 52-e21.

[2] M Dowst, A Pavuk, R Vilela, C Vilela and L Mendoza. An unusual case of cutaneous feline pythiosis. Med. Mycol. Case Rep. 2019; 26, 57-60.

[3] N Permpalung, N Worasilchai and A Chindamporn. A human pythiosis: Emergence of fungal-like organism. Mycopathologia 2019; 185, 801-12. 
http://wjst.wu.ac.th

[4] L Mendoza, L Ajello and MR McGinnis. Infection caused by the Oomycetous pathogen Pythium insidiosum. J. Mycol. Med. 1996; 6, 151-64.

[5] MN Chitasombat, P Petchkum, S Horsirimanont, P Sornmayura, A Chindamporn and T Krajaejun. Vascular pythiosis of carotid artery with meningitis and cerebral septic emboli: A case report and literature review. Med. Myco.l Case Rep. 2018; 21, 57-62.

[6] P Kammarnjesadakul, T Palaga, K Sritunyalucksana, L Mendoza, T Krajaejun, N Vanittanakom, S Tongchusak, J Denduangboripant and A Chindamporn. Phylogenetic analysis of Pythium insidiosum Thai strains using cytochrome oxidase II (COX II) DNA coding sequences and internal transcribed spacer regions (ITS). Med. Mycol. 2011; 49, 289-95.

[7] SP Appavu, L Prajna and SGK Rajapandian. Genotyping and phylogenetic analysis of Pythium insidiosum causing human corneal ulcer. Med. Mycol. 2020; 58, 211-18.

[8] T Krajaejun, M Kunakorn, R Pracharktam, P Chongtrakool, B Sathapatayavongs, A Chaiprasert, N Vanittanakom, A Chindamporn and P Mootsikapun. Identification of a novel 74-kiloDalton immunodominant antigen of Pythium insidiosum recognized by sera from human patients with pythiosis. J. Clin. Microbiol. 2006; 44, 1674-80.

[9] N Vanittanakom, J Supabandhu, C Khamwan, J Praparattanapan, S Thirach, N Prasertwitayakij, W Louthrenoo, S Chiewchanvit, and $\mathrm{N}$ Tananuvat. Identification of emerging human-pathogenic Pythium insidiosum by serological and molecular assay-based methods. J. Clin. Microbiol. 2004; 42, 3970-74.

[10] L Mendoza, F Hernandez and L Ajello. Life cycle of the human and animal oomycete pathogen Pythium insidiosum. J. Clin. Microbiol. 1993; 31, 2967-73.

[11] K Köhrer and H Domdey. Preparation of high molecular weight RNA. Meth. Enzymol. 1991; 194, 398-405.

[12] CC Hull and NC Crofts. Determination of the total attenuation coefficient for six contact lens materials using the Beer-Lambert law. Ophthal. Physiol. Opt. 1996; 16, 150-7.

[13] KJ Livak and TD Schmittgen. Analysis of relative gene expression data using real-time quantitative PCR and the 2(-Delta Delta C(T)) method. Methods 2001; 25, 402-8.

[14] JJ Garcia-Vallejo, BVH Hof, J Robben, JAV Wijk, IV Die, DH Joziasse and WV Dijk. Approach for defining endogenous reference genes in gene expression experiments. Anal. Biochem. 2004; 329, 293-9.

[15] T Romanowski, A Markiewicz, N Bednarz and KP Bielawski. Housekeeping genes as a reference in quantitative real-time RT-PCR. Postep. Hig. Med. Dosw. 2007; 61, 500-10.

[16] T Krajaejun, P Chongtrakool, K Angkananukul and TT Brandhorst. Effect of temperature on growth of the pathogenic oomycete Pythium insidiosum. Southeast Asian J. Trop. Med. 2010; 41, 1462-6.

[17] R Mani, R Vilela, N Kettler, MI Chilvers and L Mendoza. Identification of Pythium insidiosum complex by matrix-assisted laser desorption ionization-time of flight mass spectrometry. J. Med. Microbiol. 2019; 68, 574-84.

[18] NO Villa, K Kageyama, T Asano and H Suga. Phylogenetic relationships of Pythium and Phytophthora species based on ITS rDNA, cytochrome oxidase II and beta-tubulin gene sequences. Mycologia 2006; 98, 410-22.

[19] T White. Amplification and direct sequencing of fungal ribosomal RNA genes for phylogenetics. In: M Innis, D Gelfand and JJ Sninsky (Eds.). PCR protocols: A guide to methods and applications. Academic Press, New York, 1990, p. 315-22.

[20] ZL Liu and PJ Slininger. Universal external RNA controls for microbial gene expression analysis using microarray and qRT-PCR. J. Microbiol. Meth. 2007; 68, 486-96.

[21] P Vergidis, CB Moore, L Novak-Frazer, R Rautemaa-Richardson, A Walker, DW Denning and MD Richardson. High-volume culture and quantitative real-time PCR for the detection of Aspergillus in sputum. Clin. Microbiol. Infect. 2019; 26, 935-40.

[22] W Dang, X Zhang, Q Ma, L Chen, M Cao, J Miao, Y Cui and X Zhang. Selection of reference genes suitable for normalization of RT-qPCR data in glioma stem cells. Biotechniques 2020; 68, $130-7$. 
http://wjst.wu.ac.th

[23] TN Tsotetsi, NE Collins, MC Oosthuizen and KP Sibeko-Matjila. Selection and evaluation of housekeeping genes as endogenous controls for quantification of mRNA transcripts in Theileria parva using quantitative real-time polymerase chain reaction (qPCR). PloS One 2018; 13, e0196715

[24] Y Tao, AF van Peer, Q Huang, Y Shao, L Zhang, B Xie, Y Jiang, J Zhu and B Xie. Identification of novel and robust internal control genes from Volvariella volvacea that are suitable for RT-qPCR in filamentous fungi. Sci. Rep. 2016; 6, 29236.

[25] W Gaastra, LJ Lipman, AW De Cock, TK Exel, RB Pegge, J Scheurwater, R Vilela and L Mendoza. Pythium insidiosum: An overview. Vet. Microbiol. 2010; 146, 1-16.

[26] T Joseph-Horne, DW Hollomon and PM Wood. Fungal respiration: A fusion of standard and alternative components. Biochim. Biophys. Acta Bioenerg. 2001; 1504, 179-95.

[27] D Rubalcava-Gracia, J Garcia-Rincon, R Perez-Montfort, PP Hamel and D Gonzalez-Halphen. Key within-membrane residues and precursor dosage impact the allotopic expression of yeast subunit II of cytochrome c oxidase. Mol. Biol. Cell. 2019; 30, 2358-66.

[28] JL Jones, KB Hofmann, AT Cowan, D Temiakov, P Cramer and M Anikin. Yeast mitochondrial protein Pet111p binds directly to two distinct targets in COX2 mRNA, suggesting a mechanism of translational activation. J. Biol. Chem. 2019; 294, 7528-36.

[29] OM Gomaa, NS Selim, J Wee and JE Linz. RNA Seq analysis of the role of calcium chloride stress and electron transport in mitochondria for malachite green decolorization by Aspergillus niger. Fungal Genet. Biol. 2017; 105, 1-7.

[30] W Meyer, M Bauer and E Pratje. A mutation in cytochrome oxidase subunit 2 restores respiration of the mutant pet ts1402. Curr. Genet. 1997; 31, 401-7. 